Vol. 59: e16150476, January-December 2016 http://dx.doi.org/10.1590/1678-4324-2016150476 ISSN 1678-4324 Online Edition
BRAZILIAN ARCHIVES OF BIOLOGY AND TECHNOLOGY

A N INTERNATIONAL JOURNAL

\title{
Effect of Gamma Radiation on Growth and Metabolic Activities of Arthrospira platensis
}

\author{
Abo El-Fatah Abomohra1,2*; Wagih El-Shouny ${ }^{1}$; Mona Sharaf ${ }^{3}$; Mai Abo-Eleneen ${ }^{3}$ \\ ${ }^{1}$ Faculty of Sience, Tanta University, Botany Department Tanta, Egypt; ${ }^{2}$ Harbin Institute of Technology \\ Shenzhen Graduate School - School of Civil and Environment Engineering, Shenzhen, China; ${ }^{3}$ Genetic \\ Engineering and Biotechnology Institute, City for Scientific Research, Protein Research Department New Borg \\ El-Arab, Alexandria, Egypt
}

\begin{abstract}
This work aimed to study the influence of gamma radiation on the growth and production of some active substances of Arthrospira platensis. Biomass production was significantly inhibited $(p \leq 0.05)$ by 21 and $34 \%$, with respect to the control at 2.0 and $2.5 \mathrm{kGy}$, respectively. Chlorophyll-a content showed $11 \%$ reduction at 2.5 $k G y$ compared to the control. As a result of growth and Chl-a inhibition, chlorophyll productivity recorded a continuous significant decrease below the control in the cells exposed to 1, 1.5, 2 and $2.5 \mathrm{kGy}$ by 8, 12, 15 and $25 \%$, respectively after 15 days of incubation. In addition, phycobillins productivity showed significant decrease by 10 and 36\% below the control at 2 and $2.5 \mathrm{kGy}$ of gamma radiation, respectively. Protein production decreased significantly by $24 \%$ at $1.5 \mathrm{kGy}$; low doses of gamma irradiation $(0.5,1.0$ and $1.5 \mathrm{kGy})$ induced carbohydrate production by 106, 246 and 146\%, respectively. Lipid content increased significantly over the control at $0.5 \mathrm{kGy}$ of gamma irradiation by $22 \%$, which was decreased at higher doses. Interestingly, carotenoid productivity showed significant increase at all used gamma doses up to $155 \%$ over the control.
\end{abstract}

Key words: Arthrospira platensis, Spirulina platensis, Gamma radiation, Metabolic activity, Nutritional value.

\footnotetext{
${ }^{1}$ Author for correspondence: abomohra@ science.tanta.edu.eg
} 
Abomohra, AE et al.

\section{INTRODUCTION}

Arthrospira, formerly known as Spirulina, is characterized by cylindrical, multicellular trichomes in an open left-hand helix. Many reports have mentioned that Arthrospira sp. was used as food in Mexico about 400 years ago during the Aztec civilization (Abdulqader et al. 2000). However, it has been produced commercially during last 20 years for food and specialty feeds (Belay et al. 1994; Belay 1997; Kumar et al. 2013; Vo et al. 2015). A. platensis contains unusual high amounts of protein, between 26 to $72 \%$ of the dry weight, depending on growth conditions (Coca et al. 2015). It is a complete protein containing all essential amino acids, though with reduced amounts of methionine, cysteine and lysine compared to the proteins of meat, eggs and milk. However, it is superior to typical plant proteins, such as that from legumes (Babadzhanov et al. 2004). A. platensis is rich in $\gamma$-linolenic acid, provides $\alpha$ linolenic acid, stearidonic acid, eicosapentaenoic acid, docosahexaenoic acid and arachidonic acid and contains vitamins $\mathrm{B}_{1}$ (thiamine), $\mathrm{B}_{2}$ (riboflavin), $\mathrm{B}_{3}$ (nicotinamide), $\mathrm{B}_{6}$ (pyridoxine), $\mathrm{B}_{9}$ (folic acid), C (L-ascorbic acid) and $\mathrm{E}$ (e.g., $\gamma$-Tocopherol). It is a rich source of potassium and contains optimum amounts of calcium, chromium, copper, iron, magnesium, manganese, phosphorus, selenium, sodium and zinc (Tokuşoglu and üUnal 2003; Kumar et al. 2013; Benelhadj et al. 2016).

Gamma rays are high energy electromagnetic ionizing radiation emitted in the excitation of the atomic nucleus. Ionizing radiation can be quantified in terms of absorbed dose, which is the amount of ionizing radiation energy deposited per unit mass of irradiated material. The most often unit used to quantify the biological effects of ionizing radiation is the gray (Gy). One gray is equivalent to the absorption of one joule of radiation energy per kilogram of irradiated material. Ionizing radiation, nowadays, is a very important way to create genetic variability that does not exist in nature, or that is not available to the breeder (Ahloowalia and Maluszynski 2001; Lemus et al. 2002).

Many characteristics of $A$. platensis suggest that they should be excellent organisms for the investigation of biological interaction with radiation, particularly ionizing radiation. $\mathrm{Hu}$ et al. (1990) studied the effect of gamma radiation on the growth and morphology of A. platensis. They reported that low doses of gamma rays, less than $1 \mathrm{kGy}$, could stimulate its growth. Small changes in the morphology of the filament were found at doses less than $0.5 \mathrm{kGy}$. The $\mathrm{LD}_{50}$ was $1.0 \mathrm{kGy}$, while $2.5 \mathrm{kGy}$ caused $100 \%$ lethality. Wang et al. (1998) studied the effect of gamma radiation (up to $6 \mathrm{kGy}$ ) on the growth and morphology of four different strains of Arthrospira sp. and concluded that it showed resistance to gamma irradiation with stimulation of growth at low doses, while the filaments would break up or even disintegrate at high doses. Although many studies have evaluated the biological response of microalgae to high doses of gamma radiation, few studies have focused on stimulation of bioactive compounds production in $A$. platensis. The aim of the present work was to study the effect of different doses of gamma radiation on the growth and some bioactive compounds, in respect to content and productivity, in A. platensis.

\section{MATERIALS AND METHODS}

\section{The Organism and Growth Conditions}

Arthrospira platensis (SAG 257.80) was obtained from the Phycology Research Lab, Botany Department, Faculty of Science, Tanta University. It was cultivated in $300 \mathrm{~mL}$ of modified Zarrouk medium described by Aiba and Ogawa (1977). Cultures were incubated on an orbital shaker with $80 \mathrm{rpm}$ and illuminated by tubular fluorescent lamps (PHILIPS Master TLD $85 \mathrm{~W} / 840)$. The light intensity at the surface of the culturing vessels was $70 \mu \mathrm{mol}$ photons $\mathrm{m}^{-}$ ${ }^{2} \mathrm{~s}^{-1}$ at $30^{\circ} \mathrm{C}$.

\section{Irradiation of Arthrospira}

Volumes of $250 \mathrm{~mL}$ of $A$. platensis culture grown for four days were exposed to five doses of gamma rays $(0.5,1.0,1.5,2.0$ and $2.5 \mathrm{kGy})$ using $\mathrm{Co}^{60}$ as gamma rays source at the Egyptian Atomic Energy Authority (EAEA), Nasr City, Egypt. After keeping overnight in the dark, a specific volume of the dark-adapted irradiated cells was used for inoculation of $750 \mathrm{~mL}$ of modified Zarrouk medium in $1 \mathrm{~L}$ Erlenmeyer flasks at an initial $\mathrm{OD}_{750}$ of 0.06 . Optical density was measured every alternate day, while dry weight and the concentration of different 
Effect of Gamma Radiation on Growth and Metabolic Activities of Arthrospira platensis

compounds were estimated at late exponential phase.

\section{Biomass Assay}

A. platensis growth was monitored using the optical density of the culture at $750 \mathrm{~nm}\left(\mathrm{OD}_{750}\right)$ and by the determination of cellular dry weight (CDW) according to Bhattacharya and Shivaprakash (2005).

\section{Estimation of Carotenoids}

Carotenoids were measured spectrophotometrically using the modified method of Mackinney (1941). Briefly, a known volume of $A$. platensis culture was centrifuged at $4000 \mathrm{~g}$ for $10 \mathrm{~min}$. The supernatant was decanted and the same volume of methanol was added to the pellet. The mixture was incubated in a water bath at $55^{\circ} \mathrm{C}$ for $15 \mathrm{~min}$, and then centrifuged at $4000 \mathrm{~g}$ for $10 \mathrm{~min}$. The absorbance of the extract (A) was measured against blank of free methanol at 650,665 and $452 \mathrm{~nm}$. Carotenoids were estimated as $\mathrm{mg} \mathrm{mL}^{-1}$ of culture suspension using the following equation

Carotenoids $\left(\mathrm{mg} \mathrm{mL}^{-1}\right)=4.2 \mathrm{~A}_{452}-[0.0246$ $\left.\left(10.3 \mathrm{~A}_{665}-0.918 \mathrm{~A}_{650}\right)\right]$

\section{Estimation of Total Soluble Proteins}

After carotenoids extraction, residual cells were extracted using $1 \mathrm{~N} \mathrm{NaOH}$ in a boiling water bath for $2 \mathrm{~h}$ as described by Payne and Stewart (1988). Protein concentration as $\mathrm{mg} \mathrm{mL}^{-1}$ was determined according to Bradford (1976) using bovine serum albumin as a standard reference.

\section{Estimation of Total Carbohydrates}

Total carbohydrates were quantitatively determined by the phenol sulphuric acid method described by Kochert (1978) using glucose as a standard reference.

\section{Estimation of Total Phycobillins}

Fifty milliliter of algal suspension were centrifuged at $4000 \mathrm{~g}$ for $10 \mathrm{~min}$. The obtained algal cells were re-suspended in $20 \mathrm{~mL}$ of sterile distilled water. The quantitative extraction of phycobiliproteins was achieved by the combination of prolonged freezing and sonication, followed by centrifugation at $4000 \mathrm{~g}$ for $20 \mathrm{~min}$. The crude extract was completed to $50 \mathrm{~mL}$ and the concentration of total phycobillins was calculated by measuring the absorbance at 615 and $652 \mathrm{~nm}$ according to Bennett and Bogorad (1973).

\section{Estimation of Total Lipids}

Extraction of the lipids was done using chloroform: methanol (2:1). The pre-weighed glass vials containing the lipid extracts were dried at $80^{\circ} \mathrm{C}$ for $30 \mathrm{~min}$, cooled in a desiccator and weighed (Folch et al. 1957).

\section{Productivities Calculation}

Productivities of different measured parameters (biomass, Chl- $a$, carotenoids, total soluble proteins, total carbohydrates, total phycobillins and total lipids) were calculated according to the modified method of Abomohra et al. (2013)

Biomass productivity $\left(\mathrm{g} \mathrm{L}^{-1} \mathrm{~d}^{-1}\right)=\left(\mathrm{CDW}_{\mathrm{L}}\right.$ $\left.\mathrm{CDW}_{0}\right) / \mathrm{t}$

Desired product productivity $\left(\mathrm{mg} \mathrm{L}^{-1} \mathrm{~d}^{-1}\right)=\left(\mathrm{P}_{\mathrm{L}}\right.$ $\left.\mathrm{P}_{0}\right) / \mathrm{t}$

Where; $\mathrm{CDW}_{0}$ and $\mathrm{CDW}_{\mathrm{L}}$ represent the $\mathrm{CDW}(\mathrm{g}$ $\mathrm{L}^{-1}$ ) at the start of the culture and at late exponential phase, respectively. $\mathrm{P}_{0}$ and $\mathrm{P}_{\mathrm{L}}$ represent the concentration of the desired product $\left(\mathrm{mg} \mathrm{L}^{-1}\right)$ at the start of the culture and at late exponential phase, respectively, during time $(\mathrm{t})$.

\section{Statistical Analysis}

Results are presented as the mean of three replicates \pm standard deviation (SD). The statistical analyses were carried out using SAS (v 6.12). Data obtained were analyzed statistically to determine the degree of significance using one-way analysis of variance (ANOVA) at $p \leq 0.05$. Comparison of treatment means was obtained by Tukey's analysis at $p \leq$ 0.05 .

\section{RESULTS}

Growth curve of un-irradiated A. platensis cells grown in modified Zarrouk medium showed that the end of exponential phase was reached after 15 days, which was then directly followed by the death phase. Irradiated cells showed the same behavior with slight growth inhibition, which was more pronounced (28 and $40 \%$ lower than 
Abomohra, AE et al.

the corresponding control) at 2.0 and $2.5 \mathrm{kGy}$ after 20 days of incubation (Fig. 1). Biomass production showed no significant decrease at low irradiation doses, while high dose of 2.5
kGy resulted in $34 \%$ inhibition of biomass productivity (Fig. 2).

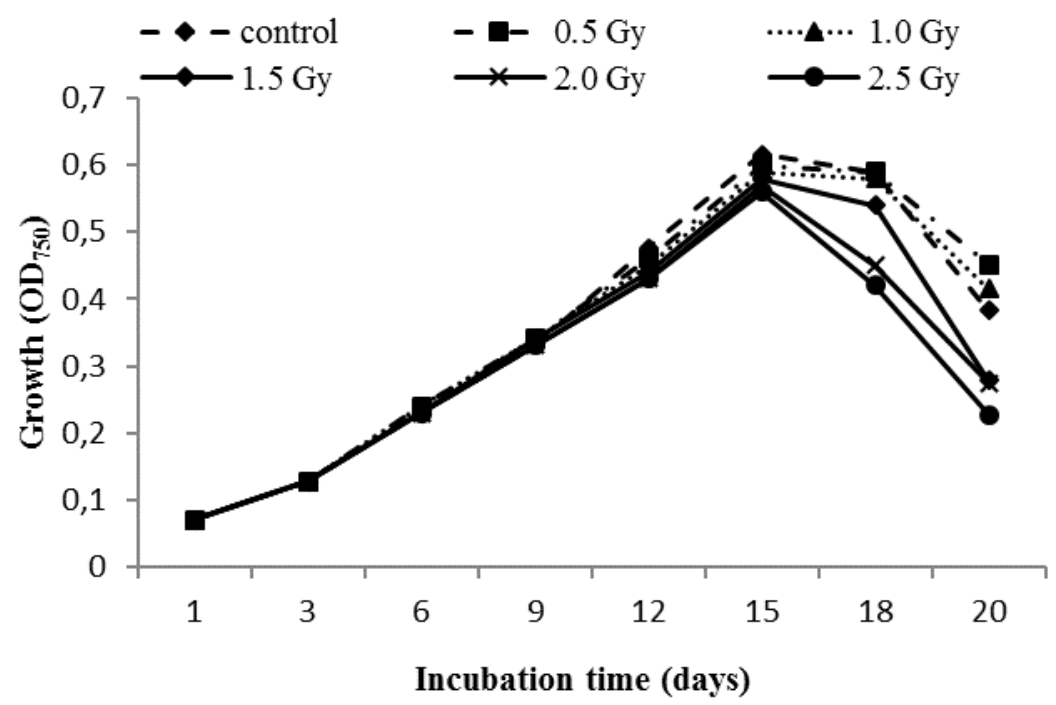

Figure 1- Effect of different doses of gamma radiation on growth of Arthrospira platensis.

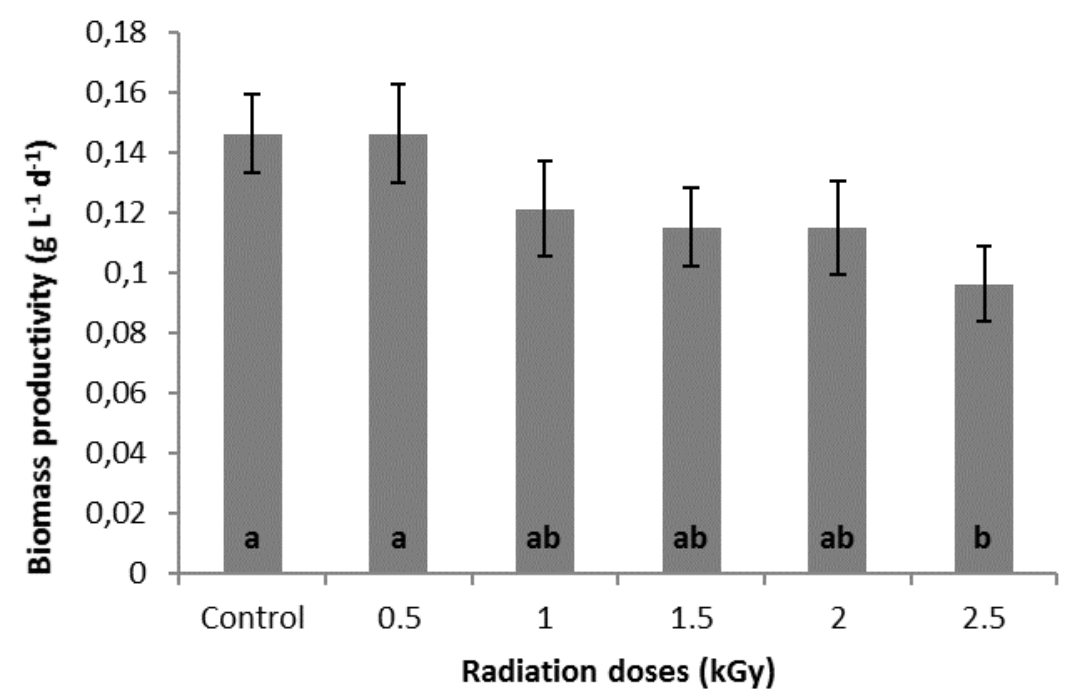

Figure 2- Effect of different doses of gamma radiation on biomass productivity of Arthrospira platensis after 15 days of incubation. Error bars represent the SD of three replicates. Columns with the same letter showed insignificant difference (at $p \leq 0.05$ ). 
Figure 3 shows the effect of gamma radiation on pigments content of A. platensis. As shown in Figure 3A, gamma irradiation significantly enhanced carotenoids accumulation in the cells at all exposure doses $(\mathrm{p} \leq 0.05)$. The increases in carotenoid content were $78,85,126,133$ and $193 \%$ over the control in $0.5,1.0,1.5,2.0$ and $2.5 \mathrm{kGy}$ irradiated cells, respectively. However, Chl- $a$ and total phycobillins content showed insignificant changes as the irradiation dose increased up to $2 \mathrm{kGy}$, while a significant reduction by 11 and $23 \%$, respectively was recorded by exposure to $2.5 \mathrm{kGy}$ (Figs. 3B and $3 \mathrm{C})$. Chl- $a$ productivity was continuously and significantly decreased $(p \leq 0.05)$ in the cells exposed to $1,1.5,2$ and $2.5 \mathrm{kGy}$ by $8,12,15$ and $25 \%$, respectively. In contrast, carotenoid productivity showed significant increase by $80,110,117$ and $155 \%$, respectively; phycobillins showed insignificant decrease (at $\mathrm{p} \leq 0.05)$ up to $1.5 \mathrm{kGy}$ and significant decrease by 10 and $36 \%$, with respect to control by exposure to 2 and $2.5 \mathrm{kGy}$, respectively (Table 1).

Exposure of A. platensis to $0.5 \mathrm{kGy}$ significantly enhanced its lipid content by $20 \%$ over the control; however, higher doses of gamma radiation led to significant reduction in lipid content (Fig. 4A). Exposure to low doses of gamma radiation resulted in significant decrease in protein content up to $17 \%$ over the control at $1.5 \mathrm{kGy}$. Interestingly, protein content was increased significantly over the control at 2.0 and $2.5 \mathrm{kGy}$ by 19 and $20 \%$, respectively (Fig. 4B). Carbohydrate content showed significant increase over the control up to $248 \%$ at $1.0 \mathrm{kGy}$; however it was decreased by 13 and $21 \%$ at 2.0 and $2.5 \mathrm{kGy}$ of gamma irradiation, respectively (Fig. 4C). As a result of increase of lipid content, lipids productivity of $A$. platensis increased significantly by $20 \%$ compared to the control at $0.5 \mathrm{kGy}$ of gamma irradiation; however lipid productivity showed significant decrease with respect to the control at the higher doses (Table 2). In addition, protein productivity decreased significantly at low doses of gamma irradiation up to $57 \mathrm{mg} \mathrm{L}^{-1} \mathrm{~d}^{-1}$ for the cells exposed to $1.5 \mathrm{kGy}$ and then significantly increased up to $78.8 \mathrm{mg} \mathrm{L}^{-1} \mathrm{~d}^{-1}$ at $2.0 \mathrm{kGy}$. Moreover, gamma irradiation enhanced carbohydrate production with maximum value of $50.8 \mathrm{mg} \mathrm{L}^{-1} \mathrm{~d}^{-1}$ at $1 \mathrm{kGy}$ (Table 2).

Table 1- Effect of different doses of gamma radiation on different pigments productivities $\left(\mathrm{mg} \mathrm{L}^{-1} \mathrm{~d}^{-1}\right)$ of $A$. platensis after 15 days of incubation.

\begin{tabular}{llll}
\hline Doses (kGy) & Carotenoids & Chl- $a$ & Phycobilins \\
\hline Control & $0.36 \pm 0.051^{\mathrm{a}}$ & $0.55 \pm 0.021^{\mathrm{a}}$ & $7.6 \pm 0.20^{\mathrm{a}}$ \\
0.5 & $0.64 \pm 0.030^{\mathrm{b}}$ & $0.53 \pm 0.021^{\mathrm{ab}}$ & $7.6 \pm 0.20^{\mathrm{a}}$ \\
1.0 & $0.65 \pm 0.031^{\mathrm{b}}$ & $0.50 \pm 0.020^{\mathrm{bc}}$ & $7.6 \pm 0.20^{\mathrm{a}}$ \\
1.5 & $0.76 \pm 0.031^{\mathrm{c}}$ & $0.48 \pm 0.019^{\mathrm{cd}}$ & $7.3 \pm 0.19^{\mathrm{a}}$ \\
2.0 & $0.78 \pm 0.030^{\mathrm{c}}$ & $0.46 \pm 0.019^{\mathrm{d}}$ & $6.8 \pm 0.26^{\mathrm{b}}$ \\
2.5 & $0.92 \pm 0.031^{\mathrm{d}}$ & $0.41 \pm 0.018^{\mathrm{e}}$ & $4.9 \pm 0.17^{\mathrm{c}}$ \\
\hline F-value & 419.3 & 17.8 & 93.2 \\
\hline p-value & 0.0001 & 0.0001 & 0.0001 \\
\hline
\end{tabular}

Each value is the mean of three replicates \pm SD

Values with the same letter in the same column showed insignificant difference (at $\mathrm{p} \leq 0.05$ ). 
Abomohra, AE et al.

Table 2- Effect of different doses of gamma radiation on lipids, proteins and carbohydrates productivities (mg $\left.\mathrm{L}^{-1} \mathrm{~d}^{-1}\right)$ of $A$. platensis after 15 days of incubation.

\begin{tabular}{llll}
\hline Doses (kGy) & Lipids & Proteins & Carbohydrates \\
\hline Control & $6.8 \pm 1.00^{\mathrm{a}}$ & $74.9 \pm 2.00^{\mathrm{a}}$ & $14.7 \pm 1.50^{\mathrm{a}}$ \\
0.5 & $8.1 \pm 0.82^{\mathrm{c}}$ & $64.1 \pm 2.11^{\mathrm{b}}$ & $30.4 \pm 1.41^{\mathrm{b}}$ \\
1.0 & $3.1 \pm 0.72^{\mathrm{b}}$ & $60.5 \pm 1.81^{\mathrm{c}}$ & $50.8 \pm 1.11^{\mathrm{c}}$ \\
1.5 & $2.8 \pm 0.80^{\mathrm{b}}$ & $57.0 \pm 1.61^{\mathrm{d}}$ & $35.9 \pm 1.11^{\mathrm{d}}$ \\
2.0 & $3.7 \pm 0.60^{\mathrm{b}}$ & $78.8 \pm 1.40^{\mathrm{e}}$ & $11.9 \pm 1.42^{\mathrm{e}}$ \\
2.5 & $3.7 \pm 0.62^{\mathrm{b}}$ & $73.8 \pm 1.52^{\mathrm{a}}$ & $8.5 \pm 1.11^{\mathrm{f}}$ \\
\hline F-value & 359.4 & 1644.2 & 5546.5 \\
\hline p-value & 0.0001 & 0.0001 & 0.0001 \\
\hline
\end{tabular}

Values are mean of three replicates \pm SD. Values with the same letter in the same column showed insignificant difference (at $\mathrm{p} \leq 0.05)$.
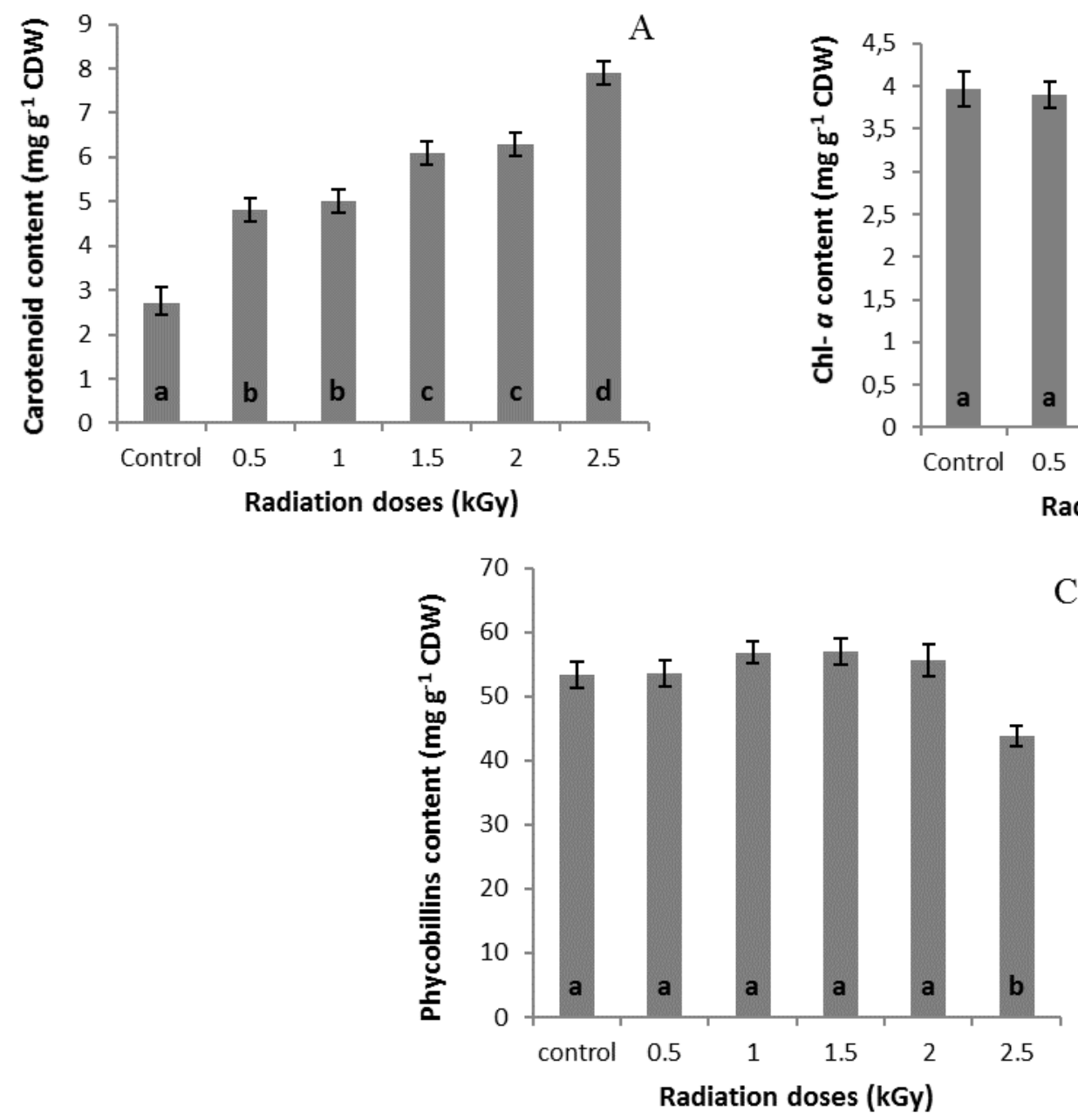

Figure 3- Effect of different doses of gamma radiation on carotenoids (A), Chl- $a$ (B) and total phycobillins (C) contents of A. platensis after 15 days of incubation. Error bars represent the SD of three replicates. Columns with the same letter showed insignificant difference (at $\mathrm{p} \leq 0.05$ ). 

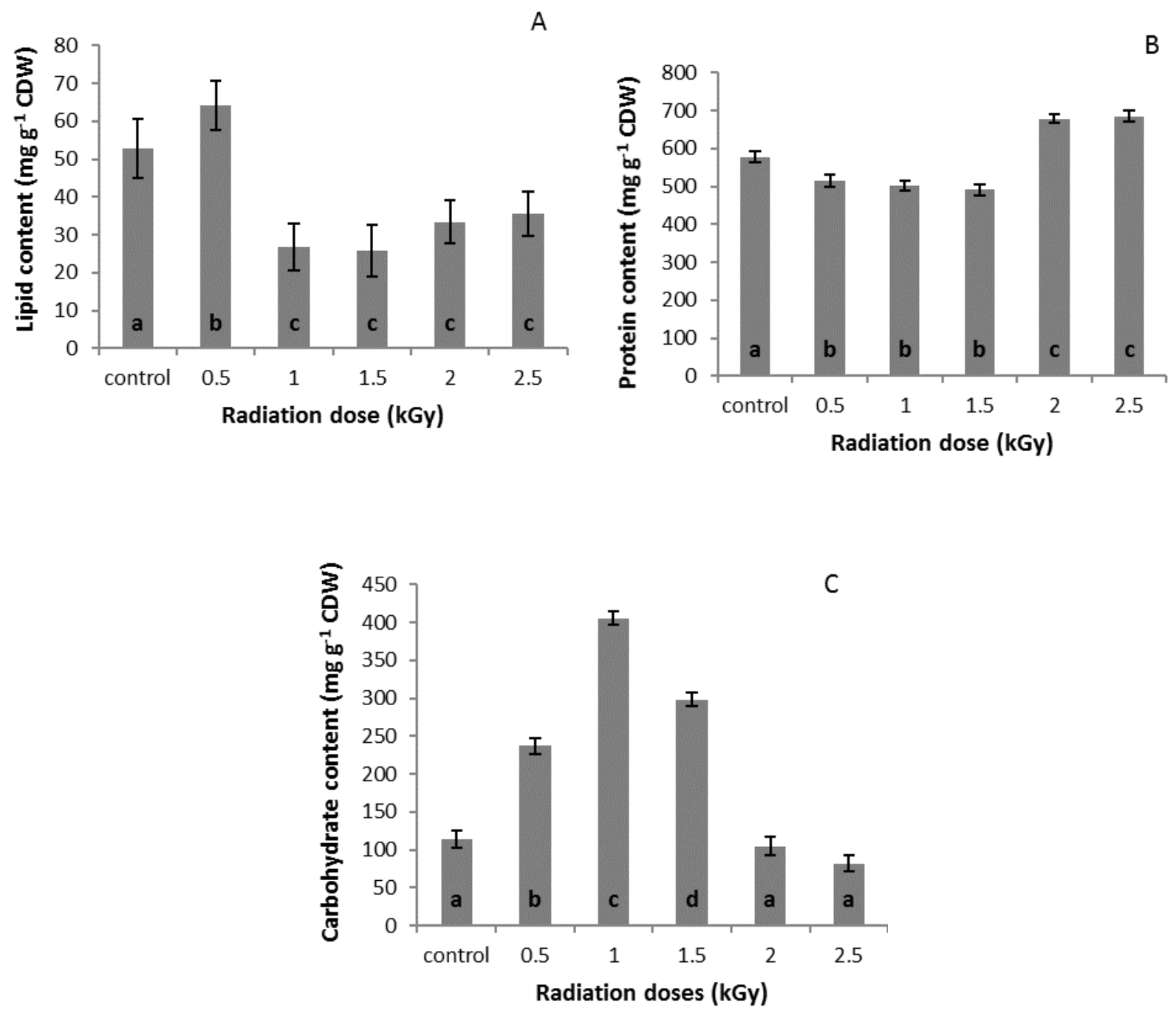

Figure 4- Effect of different doses of gamma radiation on lipids (A), proteins (B) and carbohydrates (C) contents of Arthrospira platensis after 15 days of incubation. Error bars represent the $\mathrm{SD}$ of three replicates. Columns with the same letter showed insignificant difference (at $\mathrm{p} \leq$ $0.05)$. 
Abomohra, AE et al.

\section{DISCUSSION}

Arthrospira sp. has gained a great importance as human food and pharmaceutical agent for its high protein, vitamins, carotenoids and essential fatty acids content (Vonshak et al. 1982; Belay et al. 2002; Vo et al. 2015; Benelhadj et al. 2016). Gamma radiation is one of ionizing radiations that react with atoms or molecules within the living cells to generate free radicals. The produced radicals are able to transfigure essential constituent of the cell (Mohajer 2014). In the present study, A. platensis showed a resistance to all tested gamma doses, up to 2.5 $\mathrm{kGy}$. However, exposure to gamma radiation inhibited its growth up to $30 \%$ at the maximum tested dose $(2.5 \mathrm{kGy})$. Radioresistance of $A$. platensis might be explained by the finding of Shevchenko et al. (1982) who reported that the repair of transforming DNA was performed with the participation of DNA polymerase and polynucleotide ligase, which were functioning in the cell free extract of the cyanobacterium Anacystis nidulaus. An intermediate level of radioresistance has been reported in the unicellular cyanobacterium Chroococcidiopsis sp. isolated from desert and hypersaline environments with $\mathrm{D}_{10}$ dose (dose required for 1 $\log$ cycle reduction in survival) of 3-5 kGy (Billi et al. 2000) and in the halophilic archae Halobacterium sp. NRC1, which exhibited a $\mathrm{D}_{10}$ dose of $5 \mathrm{kGy}$ (Kottemann et al. 2005). Singh et al. (2010) found that nitrogen-fixing cultures of two Anabaena strains tolerated a $5 \mathrm{kGy}$ gammaray dose without loss of survival; however, exposure to $6 \mathrm{kGy}$ of gamma rays resulted in genome disintegration but did not reduce viability.

Carotenoids produced from microalgae are nonhazardous colorants which are commonly used as enhancers of antibody production, anticancer and functional supplements ( $\mathrm{Ng}$ et al. 2011). Hence, carotenoids are of increasing demand and application in various fields (Liu et al. 2016) and, therefore, more and more researches focus on enhancement of carotenoids production in microalgae (Kuo et al. 2012; Reyes et al. 2014; Liu et al. 2016). Although the results showed that gamma radiation had a negative influence on the growth of A. platensis, positive effects on the production of some phytochemicals were recorded. Gamma irradiation enhanced the accumulation of carotenoids, which were usually enhanced under stress conditions to protect chlorophyll from photooxidative damage. Kovács and Keresztes (2002) reported that carotenoids protected chlorophyll from damage when photosynthesis light was saturated by directly accepting electronic excitation energy from triplet chlorophyll. Interestingly, low doses of gamma radiation stimulated carbohydrates and inhibited protein production, whereas high doses of gamma radiation inhibited carbohydrates and stimulated protein production. Farhi et al. (2008) and Choi et al. (2014) concluded that green microalgae exhibited radioresistance for high doses of gamma radiation (up to $6 \mathrm{kGy}$ ) with significant changes in metabolites concentrations, such as carbohydrate concentrations which decreased with increasing of gamma irradiation. This might be explained by repair mechanisms that required energy to function by burning of storage compounds for ATP production. Therefore, carbohydrates are used as cellular energy source and consumed more under stresses. The present study established that protein content of Arthrospira increased significantly over the control as a result of gamma irradiation. Farhi et al. (2008) reported that the pool of free amino acids increased even at low doses of irradiation. The increase in amino acid concentration was attributed to the increase in protein content, which played an important role in DNA repair mechanism (Reeves et al. 2015; Won et al. 2015; Yu et al. 2016).

The important role of protein synthesis for resistance of gamma rays, UV irradiation and $\mathrm{H}_{2} \mathrm{O}_{2}$ oxidative stress has been demonstrated by postulating newly synthesized proteins called "heat shock proteins", which help living cells to defend against the stress (Schorpp et al. 1984; Christman et al. 1985; Abo-Shady et al. 2008). Tammam et al. (2005) studied the differences of protein pattern and number of nucleotides of four mutant strains of Dunaliella salina obtained by gamma irradiation and found great variations in their nucleotides, which led to their alteration in the pattern of gene expression and also peptide mapping. Rivasseau et al. (2010) reported the resistance of microalgae grown in the storage pools of a nuclear reactor and investigated the metabolic impact of irradiation using NMR and neutron spectroscopy. They revealed intense protein repair activity, called 
Effect of Gamma Radiation on Growth and Metabolic Activities of Arthrospira platensis

autophagy, which resulted in stimulation of protein production. Yoon et al. (2013) found high efficiency of Spirogyra varians mutant induced by gamma radiation, which showed higher protein content comparing to the wild type. They reported 18 new expressed proteins that were suggested to be involved in photosynthesis, carbohydrate biosynthesis and energy metabolism. Kojima et al. (2011) studied the role of antioxidants to prevent the oxidative damage of gamma radiation and ATP released by low dose of gamma irradiated cells and the relation between gamma-radiation-induced ATP release and induction of cellular antioxidant thioredoxin-1 (Trx-1) via purinergic signaling. Irradiation with gamma rays, or exogenously adding ATP caused an increase in Trx-1 expression. It was further revealed that ATP generated intracellular reactive oxygen species (ROS), and thereby increasing Trx-1 expression as an adenosine receptor to ROS. They suggested that gamma radiation induced release of extracellular ATP, which induced the production of ROS via purinergic signaling leading to the promotion of intracellular antioxidants production such as pigments and proteins in response to the oxidative stress.

\section{CONCLUSIONS}

In conclusion, A. platensis showed radioresistance for high doses of ionizing gamma radiation. Gamma irradiation could be used to generate stable verities of $A$. platensis with high ability to produce certain bioactive compounds. The results confirmed the role of gamma irradiation in stimulation of lipids, proteins, carbohydrates and carotenoids as antioxidant compounds in A. platensis.

\section{ACKNOWLEDGMENTS}

We thank Walter Kiplagat (Ministry of Agriculture, Livestock and Fisheries, Baringo County, Nairobi, Kenya) for reviewing the English language of the manuscript.

\section{REFERENCES}

Abdulqader G, Barsanti L, Tredici MR. Harvest of Arthrospira platensis from Lake Kossorom (Chad) and its household usage among the Kanembu. J Appl Phycol. 2000; 12: 493-498.

Abomohra A, Wagner M, El-Sheekh M, Hanelt D. Lipid and total fatty acid productivity in photoautotrophic fresh water microalgae: Screening studies towards biodiesel production. $J$ Appl Phycol. 2013; 25: 931-936.

Abo-Shady AM, El-Naggar AH, El-Sheekh M, Abomohra A. Impact of UV-B radiation on antioxidant enzymes and protein electrophoretic pattern of the green alga Chlorococcum sp. Ann Microbiol. 2008; 58(2): 195-201.

Ahloowalia BS, Maluszynski M. Induced mutationsA new paradigm in plant breeding. Euphytica. 2001; 118(2): 167-173.

Aiba S, Ogawa T. Assessment of growth yield of a blue-green alga, Spirulina platensis, in axenic and continuous culture. J Gen Microbiol. 1977; 102: 179-182.

Babadzhanov AS, Abdusamatova N, Yusupova FM, Faizullaeva N, Mezhulmyan LG, Malikova MK. Chemical composition of Spirulina platensis cultivated in Uzbekistan. Chem Nat Compd. 2004; 40(3): 276-279.

Belay A. Mass culture of Spirulina outdoors: the Earthrise Farms experience. In: Vonshak A, editor. Spirulina platensis (Arthrospira): physiology, cell-biology and biotechnology, Taylor, Francis Ltd, London, England; 1997. p. 131-158.

Belay A. The potential application of Spirulina (Arthrospira) as a nutritional and therapeutic supplement in health management. The Journal of the American Nutraceuticals Association. 2002; 5(2): 27-48.

Belay A, Ota Y, Miyakawa K, Shimamatsu H. Production of high quality Spirulina at Earthrise Farms. In: Phang et al., editors. Algal Biotechnology in the Asia-Pacific Region, University of Malaya, Malaysia; 1994. p. 92-102.

Benelhadj S, Gharsallaoui A, Degraeve P, Attia H, Ghorbel D. Effect of $\mathrm{pH}$ on the functional properties of Arthrospira (Spirulina) platensis protein isolate. Food Chem. 2016; 194: 10561063.

Bennett A, Bogorad L. Complementary chromatic adaption in a filamentous blue-green alga. $J$ Cell Biol. 1973; 58(2): 419-435. 
Abomohra, AE et al.

Bhattacharya S, Shivaprakash MK. Evaluation of three Spirulina species grown under similar conditions for their growth and biochemicals. $J$ Sci Food Agric. 2005; 85(2): 333-336.

Billi D, Friedmann EI, Hofer KG, Caiola MG, Ocampo-Friedmann R. Ionizing-radiation resistance in desiccation-tolerant cyanobacterium Chroococcidiopsis. Appl Environ Microbiol. 2000; 66(4): 1489-1492.

Bradford MM. A rabid and sensitive method for the quantitation of microgram quantities of protein utilizing the principle protein-dye binding. Anal Biochem. 1976; 12(1-2): 248-254.

Choi JI, Yoon M, Joe M, Park H, Lee SG, Han SJ, et al. Development of microalga Scenedesmus dimorphus mutant with higher lipid content by radiation breeding. Bioprocess Biosyst Eng. 2014; 37(12): 2437-2444.

Christman MF, Morgan RW, Jacobson FS, Ames BN. Positive control of a regulon for defenses against oxidative stress and some heat-shock proteins in Salmonella typhimurium. Cell. 1985; 41: 753-762.

Coca M, Barrocal V, Lucas S, González-Benito G, García-Cubero M. Protein production in Spirulina platensis biomass using beet vinassesupplemented culture media. Food Bioprod Process. 2015; 94:.306-312.

Farhi E, Rivasseau C, Gromova M, Compagnon E, Marzloff V, Ollivier J, et al. Spectroscopic investigation of ionizing-radiation tolerance of a Chlorophyceae green micro-alga. J Phys Condens Matter. 2008; 20(10): 104216. doi: 10.1088/09538984/20/10/104216.

Folch J, Lees M, Sloane Stanley GH. A simple method for the isolation and purification of total lipids from animal tissues. J Biol Chem. 1957; 226(1): 497-509.

Hu T, Yang S, Mao Y. The effect of $\gamma$-irradiation on Spirulina platensis. Acta Agriculturae Nucleatae Sinica. 1990; 4(2): 120-124.

Kochert G. Carbohydrate determination by the phenol-sulphoric acid method. In: Hellebust JA, Craigie JS, editors. Handbook of phycological methods: physiological and biochemical methods, Cambridge University press, Cambridge; 1978. p. 95-97.

Kojima S, Takai E, Tsukimoto M. ATP released from low-dose gamma ray-irradiated cells activates intracellular antioxidant systems via purine receptors. Anti-Aging Medicine. 2011; 8(7): 108113.

Kottemann M, Kish A, Iloanusi C, Bjork S, Diruggiero J. Physiological responses of the halophilic archaeon Halobacterium sp. strain NRC1 to desiccation and gamma irradiation. Extremophiles. 2005; 9(3): 219-227.
Kovács E, Keresztes Á. Effect of gamma and UVB/C radiation on plant cells. Micron. 2002; 33(2): 199-210.

Kumar V, Singh A, Bhatnagar AK, Srivastava JN. Methyl ccis-6-octadecenoate, A new antimicrobial compound from Spirulina platensis. Asian Journal of Biochemical and Pharmaceutical Research. 2013; 3(2): 6-12.

Kuo F, Chien Y, Chen C. Effects of light sources on growth and carotenoid content of photosynthetic bacteria Rhodopseudomonas palustris. Bioresource Technol. 2012; 113: 315-318.

Lemus Y, Méndez-Natera JR, Cedeño JR, OtaholaGómez V. Radiosensibility of two cowpea (Vigna unguiculata (L.) Walp) genotypes to gamma irradiations. Revista Cientifica UDO Agrícola. 2002; 2(1): 22-28.

Liu S, Zhang G, Zhang J, Li X, Li J. Performance, carotenoids yield and microbial population dynamics in a photobioreactor system treating acidic wastewater: Effect of hydraulic retention time (HRT) and organic loading rate (OLR). Bioresource Technol. 2016; 200: 245-252.

Mackinney G. Absorption of light by chlorophyll solutions. J Biol Chem. 1941; 140: 315-322.

Mohajer S, Taha RM, Lay MM, Esmaeili AK, Khalili M. Stimulatory effects of gamma irradiation on phytochemical properties, mitotic behaviour and nutritional composition of Sainfoin (Onobrychis viciifolia Scop.). The Scientific World Journal. 2014; 854093.

$\mathrm{Ng}$ IW, Adams PG, Mothersole DJ, Vasilev C, Martin EC, Lang HP, et al. Carotenoids are essential for normal levels of dimerisation of the RC-LH1-PufX core complex of Rhodobacter sphaeroides: characterisation of R-26 as crtB (phytoene synthase) mutant. BBA-Bioenergetics. 2011; 1807(9): 1056-1063.

Payne JK, Stewart JR. The chemical composition of the thallus wall of Characiosophon rivularis (Characiosiphonaceae, Chlorophyta). Phycologia. 1988; 27(1): 43-49.

Reeves R. High mobility group (HMG) proteins: Modulators of chromatin structure and DNA repair in mammalian cells. DNA Repair. 2015; 36: 122-136.

Reyes LH, Gomez JM, Kao KC. Improving carotenoids production in yeast via adaptive laboratory evolution. Metab Eng. 2014; 21: 2633.

Rivasseau C, Farhi E, Gromova M, Ollievier J, Bligny R. Resistance to irradiation of micro-algae growing in the storage pools of a nuclear reactor investigated by NMR and neutron spectroscopies. Spectroscopy. 2010; 24(3-4): 381-385.

Schorpp M, Mallick U, Rahmsdorf HJ, Herrlich P. UV-induced extracellular factor from human 
Effect of Gamma Radiation on Growth and Metabolic Activities of Arthrospira platensis

fibroblasts communicates the UV response to nonirradiated cells. Cell. 1984; 37(3): 861-868.

Shevchenko TN, Gushcha NI, Dmitriev AP, Grodizinskii DM. In vitro repair of gammairradiated transforming Bacillus subtilis DNA extracts of blue-green algae. Genetika. 1982; 18(4): 551-554.

Singh H, Fernandes T, Apte SK. Unusual radioresistance of nitrogen-fixing cultures of Anabaena strains. J Bioscience. 2010; 35(3):427434

Tammam AA, Allam MM, Osman M. Mutagenesis of Dunaliella salina. Int J Agric Biol. 2005; 3: 477-481.

Tokuşoglu Ö, Üunal MK. Biomass nutrient profiles of three microalgae: Spirulina platensis, Chlorella vulgaris and Isochrisis galbana. J Food Sci. 2003; 68(4): 1144-1148.

Vo T-S, Ngo D-H, Kim S-K. Nutritional and Pharmaceutical Properties of Microalgal Spirulina. In: Kim S-K, editor. Handbook of Marine Microalgae: Biotechnology Advances, Elsevier Inc, UK; 2015. p. 299-308.

Vonshak A, Abeliovich A, Boussiba S, Arad S, Richmond A. Production of Spirulina biomass: Effects of environmental factors and population density. Biomass. 1982; 2(3): 175-185.
Wang Z, Xu B, Zhao X, Jiang J, Chen S. The effect of gamma-irradiation on different strains and morphological filaments of Spirulina. Acta Agriculturae Universitatis Zhejiangensis. 1998; 24(02): 121-125.

Won E, Han J, Lee Y, Kumar K, Shin K, Lee S, et al. In vivo effects of $\mathrm{UV}$ radiation on multiple endpoints and expression profiles of DNA repair and heat shock protein (Hsp) genes in the cycloid copepod Paracyclopina nana. Aquat Toxicol. 2015; 165: 1-8.

Yoon M, Choi J, Kim GH, Kim D, Park D. Proteomic analysis of Spirogyra varians mutant with high starch content and growth rate induced by gamma irradiation. Bioprocess Biosyst Eng. 2013; 36(6): 765-774.

Yu K, Zhu K, Ye M, Zhao Y, Chen W, Guo W. Heat tolerance of high bush blueberry is related to the antioxidative enzymes and oxidative proteinrepairing enzymes. Sci Hortic. 2016; 198: 36-43.

Received: December 172015 Accepted: February 192016 
Abomohra, AE et al.

\section{Erratum}

In the 01 page, that read:

“Mai Abp-Eleneen" ${ }^{3 "}$

Read:

"Mai Abo-Eleneen" ${ }^{3}$

In the 01 page, that read:

"Effect of Gamma Radiation on Growth and Metabolic Activities of Arthrospira Platensis" Read:

"Effect of Gamma Radiation on Growth and Metabolic Activities of Arthrospira platensis" 